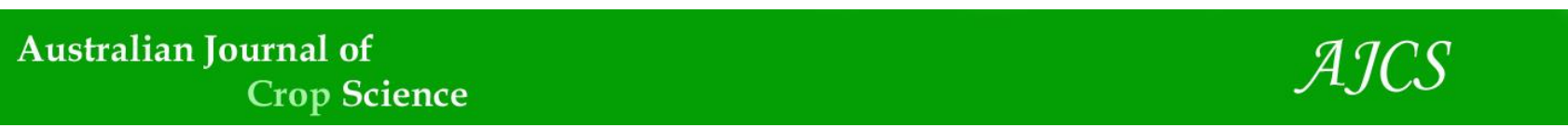

AJCS 15(05):618-621 (2021)

ISSN:1835-2707

doi: 10.21475/ajcs.21.15.05.p2387

\title{
Efficiency and persistence of insecticides with different action mechanisms applied on wheat stored pest sitophilus zeamais
}

\author{
Deivid Araújo Magano ${ }^{1}$, Ivan Ricardo Carvalho ${ }^{1}$, Ana Paula Doberstein ${ }^{1}$ \\ Murilo Vieira Louro'2, Valeria Bubans ${ }^{2}$, Lucas Drebes², Jerson Vanderlei Carus Guedes², Francine \\ Lautenchleger ${ }^{3}$, Luiz Leonardo Ferreira ${ }^{4}$, Walter Boller ${ }^{5}$
}

${ }^{1}$ Universidade Regional do Noroeste do Estado do Rio Grande do Sul, ljuí, RS, Brasil

${ }^{2}$ Universidade Federal de Santa Maria, Santa Maria, RS, Brasil

${ }^{3}$ Universidade Estadual do Centro-Oeste (Unicentro), Guarapuava, PR, Brasil

${ }^{4}$ Centro Universitário de Mineiros, Mineiros, Goiás, Brasil

${ }^{5}$ Universidade de Passo Fundo, Passo Fundo, RS, Brasil

*Corresponding author: carvalho.irc@gmail.com

\begin{abstract}
Sitophilus zeamais is the most important insect-plague among stored grain pests. The method of chemical control based on phosphine is the most used for its control, however, this method presents some inconveniences, being a costly method in labor and dangerous to the operators from the toxicological point of view. Thus, the use of preventive control, which consists of the application of liquid insecticides on the mass of grains, during the loading of the warehouse, appears as an alternative against the attack of the pests that tend to settle in the mass of grains. Thus, the objective of this work was to evaluate the efficiency and persistence of insecticides with different mechanisms of action on S. zeamais on stored wheat, simulating ideal storage conditions. An experiment was performed composed of the active ingredients: abamectin, spinosad, lambda-cyhalothrin + chlorantraniliprole, bifenthrin as a positive control, and the negative control was distilled water. The experimental design was a completely randomized block design with four replicates. The wheat was stored in Gerbox containing 250 grams, all samples being treated directly in these containers by spraying the liquid on the wheat grains. After spraying, the samples were homogenized and infested with 15 adult individuals of $S$. zeamais and deposited in an air conditioned room at $30 \pm 1{ }^{\circ} \mathrm{C}$ and relative humidity of $30 \pm 2 \%$, in order to provide conditions of high biological activity of the insects. The active ingredients spinosad and abamectin promoted a $100 \%$ control of $S$. zeamais up to 120 days of conduction of this assay. Regarding biological persistence, the active ingredients lambda-cyhalothrin + chlorantraniliprole and bifenthrin had control effects up to 60 days after application while the active principles abamectin and spinosad persisted until the end of the bioassay observations.
\end{abstract}

Keywords: Chemical control, weevil, Triticum aestivum, prophylaxis, stored grain pests.

Introduction

The growing need for products to meet the world food demand, in view of population growth, requires that the quality of the grain harvested in the crop be maintained with the minimum losses until the final consumption.

It is estimated that around 161 million tons of grain are produced annually in Brazil, according to the National Supply Company (Conab, 2011), with $20 \%$ being wasted in the harvest, transportation and storage process, reaching losses by pest attack during storage at $10 \%$ (Lorini, 1999). Pests are the major cause of physical damage, as well as being responsible for reducing the quality of grains and their byproducts destined for commercialization and consumption. The weevil, S. zeamais, is the most economically important pest, which accounts for most of the chemical control practiced in storage units. Traditionally, the most widely used method for the control of stored grain pests is the dressing, carried out through the use of fumigant insecticides, which are based on the use of aluminum phosphide or magnesium phosphide. This method is labor- intensive and dangerous to operators from a toxicological point of view, since phosphine is a colorless and highly flammable gas spontaneously in the air at a concentration above $27.1 \mathrm{~g} / \mathrm{m}^{3}$.

As an alternative of prophylaxis to the curative method, the application of protective insecticides appears, which are of great importance in storage units (Evans, 1985; White \& Leesch, 1996). This treatment consists of the application of liquid insecticides homogeneously on the mass of grains at the time of loading of the warehouse, on the conveyor belt, so that all the grains receive the insecticide. This insecticide will act as a protector to the wheat against the attack of the pests that tend to settle in the mass of grains.

The insecticides registered in the Ministry of Livestock and Supply (MAPA, 2011) are: pyrimiphos-methyl, fenitrothion, deltamethrin and bifenthrin, and there are only six commercial products, which leads us to seek tools to avoid the emergence of resistant insects. Of course, products for this purpose should have a number of advantages and safety 
standards to be approved by food safety agencies (Watters et al.,1983; Lethbridge,1989; Hagstrum \& Flinn,1996), looking for protectors that have a considerable residual effect in concentrations lethal to pests, and thus help prevent cross-resistance, that is, when a single mechanism of resistance confers resistance to two or more chemical compounds (Omoto, 2000).

Considering the small number of works in wheat stored with the use of prophylactic products (Arthur et al.,1992; Lorini et al., 2008), the objective of this work was to evaluate the efficiency and persistence of insecticides with different mechanisms of action on S. zeamais mortality, simulating ideal conditions for wheat storage.

\section{Results and discussion}

It was observed that the active ingredient bifenthrin had an efficiency of $100 \%$ of control in the first 48 hours after the application of the product, being lethal in the used dosage. The active ingredient spinosad showed a $75 \%$ control in the same first 48 hours, however its action was maximized in the evaluation performed at 96 hours. Similar result was observed for the active ingredient abamectin. The active ingredient formed by the combination of lambdacyhalothrin + chlorantraniliprole showed its maximum action potential after 144 hours. Evaluating the efficiency of the active ingredients studied, all showed efficiency against $S$. zeamais, as represented in Table 2 .

Once an insecticide solution has been prepared, its degradation may occur due to the chemical interactions between the components present in the application liquid and, especially after the application, when the insecticide is exposed to numerous agents capable of transforming it into non-toxic substances. Therefore, in order to evaluate these effects, temperature and humidity factors differ from most similar studies proposed in the literature (Arthur et al., 1992, Wintersteen \& Foster, 1992), as well as working in a range of rapid degradation, because in addition to working in a range of rapid degradation of the active principle, it was aimed to work in areas of optimum development and detoxification for insects (Rowlands, 1975; Orth \& Minett, 1975).

The importance of the use of products with different mechanisms of action is justified by the search for alternatives to pest control in stored grains, since the records of insects resistant to phosphine and other products (Pimentel et al., 2008), such as pyrethroids, are eminent, due to the ability of the Insecta class to adapt.

Bifenthrin is the only insecticide that registers among those tested, since it aims to control through different mechanisms of action. Its dosage is $16 \mathrm{ml} / \mathrm{L} \mathrm{H} \mathrm{H}_{2} \mathrm{O} /$ ton of wheat grains. The bifenthrin molecule binds to the protein associated with the $\mathrm{Na}+$ channel, preventing its closure. As a consequence, the neuron can not return to the resting condition $(-70 \mathrm{mv})$, as the activation behavior changed, causing the sodium permeability to be increased from 500 to 5000 times and, therefore, promoting a block in the transmission of nerve impulses (Guyton et al., 2006). This "knock down" or rapid paralysis effect on insects explains why all the insects inoculated in the containers with wheat treated with this product died with their elytra raised. As it has a short half-life in the environment, it does not bioaccumulate and has little mobility.

Spinosad acts by stimulating the nicotinic cholinergic receptor, whose activation initiates a sequence of events that end up leading to death of the insects. However, spinosad has a low toxicity (LD50 $=5000 \mathrm{mg} / \mathrm{kg}$ ) when compared to bifenthrin (LD50 $=531 \mathrm{mg} / \mathrm{kg}$ ) and similar control. In addition, spinosyns differ from other pesticides with natural ancestry, which is a relevant factor when it comes to overcoming resistance of insects, because by their different mode of action, control is possible more efficiently. The results found corroborate with those obtained by Lorini et al. 2008, who, however, worked with lower dosages of this active principle.

Abamectin is an acaricide widely used in agriculture and has a differentiated mechanism of action when compared to the aforementioned products because it acts on the body stimulating the release of gamma aminobutyric acid (GABA), which is an inhibitor of the presynaptic transmission of insects. The formation of GABA occurs by decarboxylation of glutamate catalyzed by the enzyme glutamate decarboxylase (GAD) (Guyton et al, 2006), presenting an intermediate toxicity (LD50 $=1086.80 \mathrm{mg} / \mathrm{kg}$ ). Therefore, a slower death occurs, with no change in insect morphology. The association of lambda-cyhalothrin with chlorantraniliprole acts through the neurotoxic action on the sensory nerves modifying the passage characteristics of voltage-sensitive sodium channels, whereas chlorantraniliprole acts on the musculature of the insects, acting through the binding of these molecules to the receptors of rianodine, in the myofribrilas of the insect muscles. Its $\operatorname{LD} 50=550 \mathrm{mg} / \mathrm{kg}$ makes it as lethal as bifenthrin. This insecticide presented a slower action, however, it was possible to perceive that the insects, after contact with the product, ceased the food activity, not causing severe damage to the grains.

All products tested showed persistence up to 60 days, as can be seen in Figure 1. The control treatment showed, on average, 620 insects coming from the $\mathrm{F} 1$ generation, and at the end of the evaluations were counted on, average, 3620 insects inside the gerbox with wheat grains.

However, it was possible to verify that the action of bifenthrin at higher temperatures, as in the proposed trial, is reduced over time when compared to abamectin and spinosad, where up to 120 days showed $100 \%$ biological efficiency, these principles persist in the grain in an active way, corroborating with the studies carried out by Pimentel et al., (2005), who evaluated bifenthrin in stored corn. It is important to emphasize that this essay addresses only the factors related to the efficiency/persistence of the products tested, generating the need to carry out new studies from a toxicological point of view, such as residue analysis on wheat grain and its by-products.

\section{Materials and methods}

The assay was carried out in the Laboratory of Integrated Pest Management of the Federal University of Pelotas (LabMIP-UFPel), using adults of $S$. zeamais, being kept under controlled conditions (temperature $25 \pm 1^{\circ} \mathrm{C}, \mathrm{RH} 70 \pm 10 \%$ ). The taxonomy of the species was carried out by the entomological Museum Ceslau Biezanco of the Phytosanitary Department of FAEM.

The treatments were composed of the active ingredients [mL.L-1/ton]: [(abamectin) 16], [(spinosade) 16], [(lambdacyhalothrin + chlorantraniliprole) 16], [(bifenthrin) 16] as a positive control, and the negative control only with distilled 
Table 1. Agrochemicals used, commercial brand, formulation and concentrations of the active ingredients used in conducting the experiment.

\begin{tabular}{|c|c|c|c|}
\hline Commercial brand & Active ingredient & Formulation & C.a.i. in the mixture (\%) \\
\hline Prostore $25 \mathrm{CE}$ & Bifenthrin & CE & 0.04 \\
\hline Ampligo & Chlorantrinyliprole + Lambda cyhalothrin & SC & $0.016+0.008$ \\
\hline Tracer & Spinosin & SC & 0.768 \\
\hline Vertimec & Abamectin & EC & 0.0288 \\
\hline
\end{tabular}

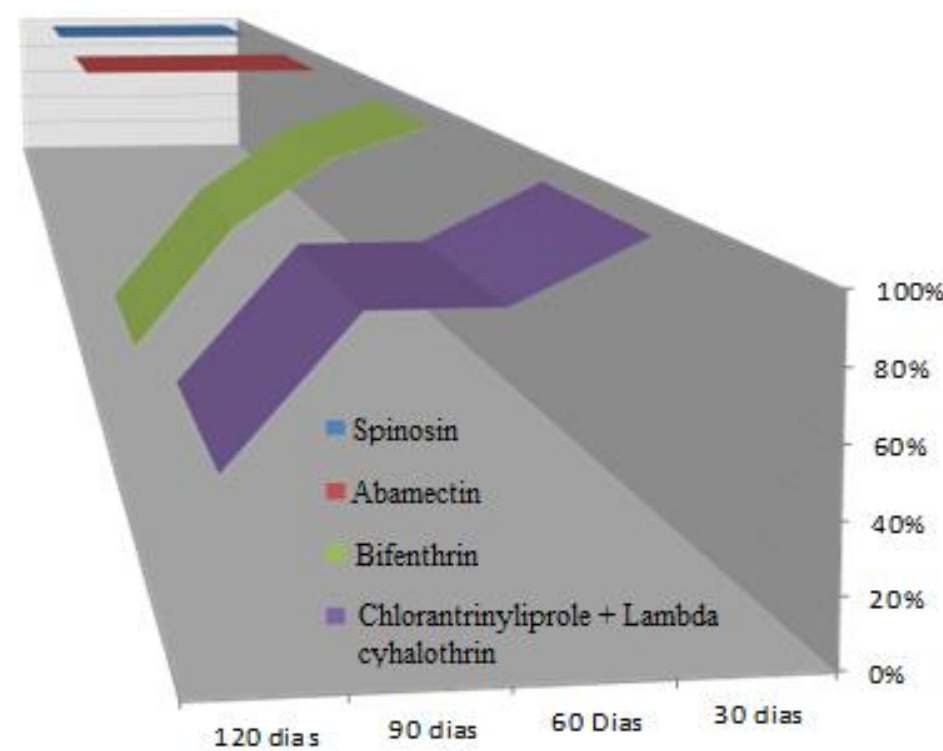

Fig 1. Persistence of protective insecticides with different mechanisms of action on Sitophilus zeamais under laboratory conditions

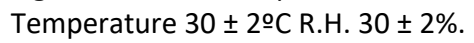

Table 2. Effect of insecticide treatment on control of adults S.zeamais evaluated 144 hours after exposure to stored wheat mass at $30 \pm 2^{\circ} \mathrm{C}$ and $\mathrm{RH} 30 \pm 5 \%$. LabMIP UFPel, Pelotas, 2011 .

\begin{tabular}{|ll|}
\hline Treatment & Average Mortality \\
\hline Bifenthrin & $15.00 \pm 0.00 \mathrm{a}$ \\
\hline Spinosad & $14.25 \pm 0.48 \mathrm{a}$ \\
\hline Abamectin & $13.75 \pm 0.52 \mathrm{a}$ \\
\hline Chlorantrinyliprole + Lambda cyhalothrin & $9.25 \pm 0.23 \mathrm{~b}$ \\
\hline Control & $0.00 \pm 0.00 \mathrm{c}$ \\
\hline C.V & $6.36 \%$ \\
\hline
\end{tabular}

water, with only bifenthrin being registered for the control of grain pests stored in said dosage. All other products tested for lack of results on efficiency and persistence in control of S. zeamais in stored wheat were tested with the dosage taking into consideration the dosage of the product already registered to bifenthrin. Complementary data on pesticides are available in Table 1.

The wheat was stored in Gerbox containing 250 grams of grains, all samples being treated directly in these containers by spraying the liquid on the grain with an empty conical nozzle series $X$ pressure of $40 \mathrm{lbs} / \mathrm{in}^{2}$.

After spraying, the samples were homogenized and infested with 15 adult individuals of Sitophilus zeamais and conditioned in an air conditioned room at $30 \pm 1^{\circ} \mathrm{C}$ and relative humidity of $30 \pm 2 \%$, in order to provide conditions of high biological activity of the insects.

The experimental design was a completely randomized design with four blocks containing four replicates. Efficacy measurements were performed every 48 hours after treatment, and were reinfested continuously every week. The parameter used to measure the efficiency of the active ingredients was obtained by evaluating the number of dead insects present in the grain mass. Mortality results were submitted to analysis of variance (ANOVA) and Student's $t$ test $(p \leq 0.05)$. To evaluate the persistence, evaluations were considered every $30,60,90$ and 120 days, and the mortality of the individuals present in the wheat grain mass was evaluated. Abbott's formula was used to correct the values of efficiency and persistence.

\section{Conclusions}

According to the observed, it was possible to conclude that the compounds spinosad and abamectin are potentially promising as protectors in the treatment of grains when the biological target is Sitophilus zeamais, since they promote an efficient control (superior to $80 \%$ ) when compared to the other protective pyrethroids which have been used in the market so far. 
Regarding the persistence evaluated up to 120 days, spinosad and abamectin presented higher persistence on the biological target in wheat grains stored under laboratory conditions compared to the active ingredients bifenthrin and lambdacialotrin + chlorantriniliprole.

\section{References}

Arthur FH, Throne JE, Simonaitis RA (1992) Degradation and biological efficacy of chloripyriphos-methyl) on stored wheat at five temperatures and three moisture contents. Journal of Economic Entomology. 85: 1994-2002.

Canteri MG, Althaus RA, Virgens Filho JS, Giglioti EA, Godoy CV (2001) Sasm - Agri : Sistema para análise e separação de médias em experimentos agrícolas pelos métodos Scoft - Knott, Tukey e Duncan. Revista Brasileira de Agrocomputação. 1: 18-24.

Conab (2011) Décimo-primeiro Levantamento da avaliação da safra de grãos 2010/2011. Accessed on: Aug 31 ${ }^{\text {st }}, 2011$. Online. Available at: http://www.conab.gov.br/OlalaCMS/uploads/arquivos/11 _08_09_11_44_03_boletim_agosto-2011.pdf

Evans NJ (1985) The effectiveness of various insecticides on some resistant beetle pest of stored products from Uganda. Journal of Stored Products Research, 21: 105-109. Hagstrum DW, Flinn PW (1996) Integrated pest management. In: Subramanyan $\mathrm{BH}$, Hagstrum DW. Integrated Management of insects in stored Products. New York: Marcel deckker. 9: 399-408.

Lethbridge $G$ (1989) An industrial view of microbial inoculants for crop plants. In: Campbell R, Macdonald RM. (Eds.) Microbial inoculation of crop plants. Oxford: Pergamon Press, 11-28.

Lorini I, Beckel H, Schneider S (2008) Eficácia de Spinosad e IGR Plus no controle das pragas de grãos armazenados Rhyzopertha dominica e Sitophilus zeamais.Passo Fundo: Embrapa Trigo, 9 p. html. (Embrapa Trigo. Comunicado
Técnico Online, 237). Available at: <http://www.cnpt.embrapa.br/biblio/co/p_co237.htm>.

Mapa (2011) - Ministério da Agricultura, Pecuária e Abastecimento - Coordenação-Geral de Agrotóxicos e Afins/DFIA/DAS. Sistema Agrofit. Available at: http://extranet.agricultura.gov.br/agrofit_cons/principal_ agrofit_cons. Online. Accessed on: Jun 20th 2011.

Orth RA, Minett W (1975) lodometric analysis and shelf life of malathion in formulations. Pesticide Science, (6): 217221.

Pimentel MAG, Faroni LRD, Guedes RNC, Gonçalves JR., Oliveira CRF (2005) Eficácia biológica de bifentrina aplicado em milho armazenado sob diferentes temperaturas. Revista Bras. de Engenharia Agrícola e Ambiental. 9(2): 263-267.

Pimentel MAG, Faroni LRD, Batista MD, Silva FH (2008) Resistance of stored-product insects to phosphine. Pesquisa Agropecuaria Brasileira, Brasília. 43(12): 1671 1676.

Rowlands DG (1975) The metabolism of contact insecticides in stored grain. Residue Rev. 58: 113-155.

Thomson GD, Dutton R, Sparks TC (2000) Spinosad - a case study: an example from a natural products discovery programme. Pest Management Science. 56: 696-702.

Watters FL, White NDG, Coté D (1983) Effect of temperature on the toxicity and persistence of three pyrethroid insecticides applied to fir plywood for the control os Tribolium castaneum. Journal of Economic Entomology. 76: 11-16.

White NDG, Leesch JG (1996) Chemical control. In B. Subramanyam \& D.W. Hagstrum (eds.), Integrated management of insects in stored products. New York: Marcel Dekker, 287-330.

Wintersteen WK, Foster DE (1992) Degradation of malathion as a function of grain drying systems. Journal of Economic Entomology, Lanham. 85: 1015-1022. 